\title{
DETERMINAN KEBERLANGSUNGAN POSYANDU LANSIA DILIHAT DARI PERSEPSI PROVIDER DAN RECEIVER DI KECAMATAN MARGA TABANAN BALI
}

\author{
Determinants Sustainability Views from The Perception of Geriatric Integrated \\ Health Post Providerand Receiver in Tabanan - Bali \\ Indra Peratiwi ${ }^{1}$, Hesteria Friska Armynia $S^{2}$ \\ STIKES Advaita Medika Tabanan \\ (indra.peratiwi2013@gmail.com)
}

\begin{abstract}
ABSTRAK
Latar belakang: Indonesia termasuk kedalam kategori 5 besar negara dengan jumlah penduduk lansia terbesar di dunia. Meningkatnya umur harapan hidup merupakan salah satu indikator meningkatnya kesehatan masyarakat di daerah tersebut. Apabila jumlah lansia semakin banyak, maka semakin baik tingkat status kesehatan masyarakat di daerah tersebut. Untuk meningkatkan kesehatan lansia diperlukan adanya posyandu lansia di setiap desa.

Tujuan Penelitian : Penelitian ini bertujuan untuk mengetahui keberlanjutan posyandu lansia dilihat dari persepsi pemberi dan penerima layanan di Kecamatan Marga.

Metode : Wawancara mendalam dilakukan pada lansia yang aktif dan tidak aktif, camat, kepala puskesmas, petugas puskesmas, kepala desa yang aktif dan tidak aktif, dan kader lansia.

Hasil: Hasil penelitian didapatkan bahwa pengetahuan lansia terhadap posyandu lansia menjadi faktor pendorong terhadap keberlanjutan posyandu lansia baik dari posyandu yang aktif maupun tidak aktif. Namun dilihat dari pemberi layanan terbentuknya posyandu lansia terkesan dipaksakan, hal tersebut disebabkan karena tuntutan dari berbagai pihak seperti dinas kesehatan, puskesmas serta dari desa itu sendiri karena tuntutan akan diadakannya lomba desa. Dilihat dari faktor pemungkin, ketersediaan SDM dan sarana prasarana sangat mempengaruhi keberlanjutan posyandu lansia. Dilihat dari faktor penguat, dukungan petugas puskesmas,camat, kepala desa, keluarga serta teman sebaya sangat mempengaruhi keberlanjutan posyandu lansia. Informan yang memanfaatkan posyandu lansia cenderung lebih mengharapkan agar posyandu lansia tetap berlanjut, namun berbanding terbalik dengan informan yang tidak memanfaatkan posyandu lansia. Ada beberapa lansia yang tidak memanfaatkan posyandu lansia menyatakan tidak memerlukan posyandu lansia karena berbagai alasan, salah satunya karena tidak adanya waktu luang serta merasa aman akan kesehatannya karena sudah mempunyai jaminan kesehatan. Oleh sebab itu diperlukan adanya sosialisasi dari pemangku kebijakan kepada masyarakat agar lansia bisa memanfaatkan posyandu lansia.
\end{abstract}

Simpulan: Ada banyak faktor yang mempengaruhi keberlanjutan posyandu lansia, yang berasal dari pemberi dan penerima layanan. 
Kata kunci: determinan, keberlanjutan, posyandu lansia,puskesmas, studi kualitatif

\section{ABSTRACT}

Background: Indonesia falls into the category of the top 5 countries with the largest elderly population in the world. Increasing life expectancy is one indicator of increasing public health in the area. If the number of elderly people is increasing, the better the level of public health status in the area. To improve the health of the elderly there needs to be an elderly posyandu in each village.

The Aim : This study aims to determine the sustainability of the elderly posyandu seen from the perceptions of the providers and recipients of services in Marga District.

Method: In-depth interviews were conducted on active and inactive elderly people, sub-district heads, puskesmas heads, health center officers, active and inactive village heads, and elderly cadres.

Results: The results of the study showed that the knowledge of the elderly towards the elderly posyandu became a driving factor for the sustainability of the elderly posyandu both from active and inactive posyandu. But seen from the service providers, the formation of the elderly posyandu seemed to be forced, this was due to demands from various parties such as the health office, puskesmas as well as from the village itself because of demands for a village race. Judging from the enabling factors, the availability of human resources and infrastructure greatly influences the sustainability of the elderly posyandu. Judging from the reinforcing factors, the support of the puskesmas staff, sub-district heads, village heads, families and peers greatly influences the sustainability of the elderly posyandu. Informants who used the elderly posyandu tended to expect the elderly posyandu to continue, but it was inversely proportional to the informants who did not use the posyandu for the elderly. There are some elderly people who do not use the elderly posyandu stating that they do not need an elderly posyandu for various reasons, one of which is the lack of free time and feeling safe about their health because they already have health insurance. Therefore, there is a need for socialization from policy makers to the community so that the elderly can use the elderly posyandu.

Conclusion: There are many factors that influence the sustainability of the elderly posyandu, which originates from the service provider and recipient.

Keywords: determinant, sustainability, elderly posyandu, puskesmas, qualitative study

\section{PENDAHULUAN}

Besarnya jumlah penduduk lansia di Indonesia di masa depan membawa dampak positif maupun negatif. Berdampak positif, apabila penduduk lansia berada dalam keadaan sehat, aktif dan produktif. Disisi lain, besarnya jumlah jumlah penduduk lansia menjadi beban jika lansia memiliki masalah penurunan kesehatan yang berakibat pada peningkatan biaya pelayanan kesehatan, penurunan 
pendapatan/penghasilan, peningkatan disabilitas, tidak adanya dukungan sosial dan lingkungan yang tidak ramah terhadap penduduk lansia (Abikusno, 2012).

Data proyeksi penduduk diperkirakan tahun 2017 terdapat 23,66 juta jiwa penduduk lansia di Indonesia $(9,03 \%)$. Diprediksi jumlah penduduk lansia tahun 2020 (27,08 juta), tahun 2025 (33,69 juta), tahun 2030 (40,95 juta) dan tahun 2035 (48,19 juta). Berdasarkan data Kementerian Kesehatan RI tahun 2017 didapatkan bahwa, terdapat tiga provinsi dengan jumlah lansia paling besar yaitu; Yogyakarta (13,81\%), Jawa Tengah (12,59\%) dan Jawa Timur (12,25\%). Sementara itu, terdapat tiga provinsi dengan jumlah lansia terkecil yaitu; Papua (3,20\%), Papua Barat (4,33\%) dan Kepulauan Riau (4,35\%) (Depkes, 2010).

Meningkatnya umur harapan hidup merupakan salah satu indikator meningkatnya kesehatan masyarakat di daerah tersebut. Apabila jumlah lansia semakin banyak, maka semakin baik tingkat status kesehatan masyarakat di daerah tersebut. Pertambahan penduduk lansia ini disebabkan oleh semakin membaiknya pelayanan kesehatan dan semakin meningkatnya usia harapan hidup masyarakat di Indonesia.

Provinsi Bali menduduki peringkat keempat dari kelima Provinsi dengan jumlah lansia tertinggi di Indonesia. Pada tahun 2017 jumlah lansia di Provinsi Bali mencapai 11,02\% (517.500 jiwa). Di Provinsi Bali terdapat 9 Kabupaten, dari kesembilan Kabupaten tersebut Kabupaten Tabanan tergolong Kabupaten dengan jumlah penduduk lansia cukup tinggi yaitu mencapai 53.584 jiwa. Menurut Dinas Kesehatan Kabupaten Tabanan (2017) menunjukkan jumlah lansia di Kabupaten Tabanan pada tahun 2017 sebanyak 53.584 jiwa, masing-masing Kecamatan yang ada di Kabupaten Tabanan terdapat lansia. Salah satu Kecamatan dengan jumlah lansia tertinggi berada di Kecamatan Marga. Pada tahun 2017 jumlah lansia di Kecamatan Marga sebanyak 4.649 jiwa, yang terdiri dari 2275 lansia laki-laki dan 2374 lansia perempuan. Namun dari total jumlah lansia yang ada di Kecamatan Marga yang mendapatkan pelayanan kesehatan hanya 523 jiwa, jumlah lansia yang mendapat pelayanan kesehatan tersebut tergolong sangat kecil dibandingkan dengan jumlah lansia yang ada di Kecamatan Marga.

Untuk mewujudkan kebijakan dan program kesehatan lanjut usia pemerintah Kabupaten Tabanan mencanangkan pelayanan pada lansia yaitu mulai dari jenjang Posyandu Lansia ditingkat masyarakat. Pelayanan kesehatan ditingkat dasar melalui Puskesmas, dan pelayanan kesehatan di tingkat lanjutan melalui Rumah Sakit. Posyandu merupakan salah satu pelayanan di tingkat masyarakat, Posyandu Lansia memiliki arti yang sama penting dengan Posyandu Balita. Posyandu Lansia merupakan suatu kegiatan kesehatan di tingkat paling dasar untuk para lansia yang diselenggarakan dari, oleh dan untuk para lansia yang dibantu oleh petugas kesehatan untuk pelaksanannya setiap hari.

Berdasarkan latar belakang masalah yang telah diuraikan diatas, maka rumusan masalah dalam penelitian ini adalah: "Faktor-faktor apa saja yang mempengaruhi keberlangsungan posyandu lansia di Kecamatan Marga dilihat dari sudut pandang pemberi dan penerima layanan?"

Penelitian ini bertujuan untuk mengetahui keberlanjutan posyandu lansia dilihat dari sudut pandang pemberi dan penerima layanan. 


\section{METODE PENELITIAN}

Rancangan penelitian ini menggunakan rancangan penelitian kualitatif. Pengumpulan data (pada bulan Maret 2018 selama 4 minggu) melibatkan 17 informan. Sumber informan berasal dari lima lansia yang memanfaatkan dan lima tidak memanfaatkan posyandu, satu orang kepala puskesmas,satu orang camat, satu orang petugas puskesmas, dua orang kepala desa pada posyandu yang aktif dan tidak aktif serta dua orang kader lansia. Informan dipilih secara purposive, berdasarkan pertimbangan tujuan penelitian dan kemampuan responden dalam menyediakan informasi.

Data kualitatif dikumpulkan melalui wawancara mendalam terhadap 17 informan. Pertanyaan informan terkait dengan pedoman wawancara terkait pengetahuan yang dimiliki terkait pelaksanaan posyandu lansia, ketersediaan sumber daya manusia (SDM) kesehatan, sarana prasarana, dukungan dari berbagai pihak seperti petugas, keluarga, tokoh masyarakat, hambatan-hambatan pada saat pelaksanaan posyandu serta strategi yang bisa dilakukan untuk keberlanjutan posyandu lansia. Selain itu untuk pelaksanaan posyandu lansia dilakukan melalui observasi langsung dengan daftar tilik yang telah dibuat oleh peneliti sebelumnya.

Sebelum wawancara/diskusi, setiap informan telah diberikan penjelasan dan mengisi lembar persetujuan (informed consent). Analisis data hasil wawancara dilakukan secara tematik, yaitu mengorganisasikan, mengurutkan data kedalam pola, kategori dan satu uraian dasar, sehingga dapat ditemukan tema tertentu. Untuk menjamin keabsahan data, pemeriksaan jawaban informan dilakukan dengan teknik triangulasi sumber dan catatan observasi.

\section{HASIL PENELITIAN DAN PEMBAHASAN}

\section{Faktor Predisposisi}

Keberlanjutan posyandu lansia berdasarkan hasil penelitian dipengaruhi oleh faktor predisposisi. Faktor predisposisi merupakan faktor pendorong terhadap terjadinya suatu perilaku. Faktor predisposisi dipengaruhi oleh variabel pengetahuan, pendidikan, umur, jenis kelamin dan sosial ekonomi dan persepsi dari lansia.

Informan yang memanfaatkan posyandu lansia menyatakan tujuan mengikuti posyandu lansia yaitu supaya lansia menjadi sehat, bisa bertukar pikiran dengan teman sesama lansia, menghilangkan stres, dan tempat berkumpul para lansia. Seperti ungkapan berikut ini:

"Kalau tujuannya itu (sambil berpikir) supaya kita sehat, disamping kita bisa sehat supaya kita bisa bertukar pikiran dengan teman sebaya serta bisa menghilangkan stres." (Informan A1)

Informan yang tidak memanfaatkan posyandu lansia kurang mengetahui tujuan dibentuknya posyandu lansia, mereka hanya mengetahui untuk meningkatkan kesehatan saja. Seperti yang dikemukakan berikut ini:

“...untuk meningkatkan kesehatan ” (Informan B1, lansia yang tidak memanfaatkan posyandu lansia) 
Lansia merasakan mendapatkan keuntungan jika datang ke posyandu seperti bisa mengetahui kondisi kesehatannya secara cepat. Sehingga hal tersebut yang mendorong lansia untuk mengunjungi posyandu.

“...yang mendorong saya datang ke posyandu karena saya merasakan mendapatkan keuntungan jika datang ke posyandu, seperti kondisi saya bisa diketahui secara cepat. Apakah tensi naik, kadar gula darah naik atau bagaimana." (Informan A3, lansia yang aktif datang ke posyandu)

Informan lansia menyatakan tertarik untuk datang ke posyandu karena mereka merasa puas terhadap pelayanan yang diberikan saat pelaksanaan posyandu lansia, dimana mereka merasa lebih sehat semenjak mengikuti posyandu lansia, selain itu mereka merasa puas karena di posyandu dilakukan pemeriksaan laboratorium seperti pemeriksaan darah. Seperti yang dikemukakan berikut ini:

"saya tertarik datang karena pelayanannya memuaskan,... selain itu saya sudah merasakan manfaatnya, dimana saya merasa lebih sehat semenjak ikut posyandu." (Informan A2, lansia yang aktif datang ke posyandu).

Namun ada juga informan yang memanfaatkan posyandu lansia merasakan tidak puas atau biasa saja terhadap pelayanan posyandu yang diberikan, sehingga menyebabkan daya tarik lansia untuk datang ke posyandu menjadi berkurang. Hal tersebut disebabkan karena lansianya disuruh untuk meminta sumbangan kepada donatur untuk keberlanjutan posyandu, pemeriksaan tidak dilakukan oleh dokter, obatnya sedikit dan lansia tidak merasakan perubahan kesehatan terhadap tubuhnya. Seperti ungkapan berikut ini:

“..kurang puas, karena obat-obatannya dan alat lab itu juga kurang, rasanya ga juga puas...iya, sampai minta-minta sumbangan itu.....masalah itu juga kurang puas kalau tidak diperiksa oleh dokter.jadinya berkurang daya tarik kita itu untuk datang” (Informan A1, lansia yang memanfaatkan posyandu lansia)

\section{Faktor Pemungkin}

Faktor pemungkin yang mempengaruhi lansia dalam berkunjung ke posyandu lansia yaitu sarana prasarana, ketersediaan SDM. Informan yang memanfaatkan posyandu lansia menyatakan bahwa yang memberikan pelayanan di posyandu lansia rata-rata berjumlah 4-5 orang dari puskesmas yang terdiri dari dokter, perawat, bidan dan kader. Selain petugas yang ada di puskesmas juga ada kader lansia dari masing-masing dusun. Seperti yang dikemukakan berikut ini:

"biasanya berlima dari petugas puskesmas, perawat..dokter ada satu..." (Informan A3, informan yang aktif datang ke posyandu lansia)

Hal diatas didukung berdasarkan hasil wawancara dengan petugas puskesmas diperoleh informasi bahwa tenaga kesehatan yang melaksanakan kegiatan di posyandu lansia terdiri dari 4 orang. Dimana terdapat petugas puskesmas, dokter, kader, bidan dan perawat. Seperti yang dikemukakan berikut ini: 
"Biasanya sih kita empat orang..iya tapi kan dibantu juga dengan kader, kalau dokter ikut juga, iya.. (sambil menggangguk). Iya dokter, bidan dan perawat...." (Informan IK2, petugas puskesmas)

Namun semua informan yang memanfaatkan posyandu lansia, menyatakan bahwa pemeriksaan yang dilakukan oleh dokter, intesitasnya jarang. Bisa 2-3 bulan baru ada pemeriksaan itupun bisa datang dan bisa juga tidak datang. Lebih sering bidan atau perawat yang melakukan pemeriksaan, itupun jumlah petugasnya kadang banyak dan kadang juga sedikit sehingga pada saat pemeriksaan petugas menjadi kewalahan dengan jumlah lansia yang ada. Seperti yang dikemukakan berikut ini:

"Kalau sebenarnya kan tiap bulan, namun 2-3 bulan sekali biasanya...ya, pemeriksaan dokter biasanya 2-3 bulan sekali, itupun kadang dilakukan kadang tidak...kurang rasanya itu....soalnya lansia kan jumlahnya banyak, kadang-kadang bisa berebut dalam satu hari jadinya agak kewalahan." (Informan A1, informan yang aktif datang ke posyandu lansia)

Berdasarkan hasil wawancara pernyataan diatas dibenarkan oleh kader Desa Kuwum. Dimana dinyatakan bahwa dulu pernah dilakukan pemeriksaan oleh dokter, namun saat ini pemeriksaan oleh dokter jarang dilakukan, seperti pernyataan berikut ini:

"Waktu dulu pernah ada dokter, tapi sekarang agak-agak jarang." (Informan IK5, kader lansia)

\section{Faktor Penguat}

Faktor penguat yang mempengaruhi kunjungan ke posyandu lansia yaitu adanya dukungan dari petugas kesehatan, dukungan sosial dan dukungan keluarga. Dukungan atau support dari orang lain atau orang terdekat sangat berperan dalam keberhasilan keberlanjutan posyandu lansia. Semakin besar dukungan yang didapatkan untuk melakukan kunjungan ke posyandu lansia semakin besar pula motivasi dari lansia untuk berkunjung ke posyandu lansia.

Informan yang memanfaatkan posyandu lansia menyatakan mendapatkan dukungan dari petugas puskesmas, berupa selalu diberikan pengarahan dimana mereka disarankan untuk rajin mengikuti senam supaya tetap sehat. seperti ungkapan berikut ini:

"iya kita didukung oleh petugas puskesmas terus diberitahu oleh petugas agar rajin mengikuti senam supaya sehat." (Informan A2, lansia yang aktif memanfaatkan posyandu lansia)

Sedangkan semua informan yang tidak memanfaatkan posyandu lansia mengatakan tidak mendapatkan dukungan sama sekali dari petugas puskesmas sehingga di desanya tidak berlangsung posyandu lansia, seperti ungkapan berikut ini:

"Orang dari puskesmas aja ga pernah turun. Dukungan puskesmas sangat kurang kalau saya lihat. Jadinya disini tidak ada posyandu lansia" (Informan B4, lansia yang tidak memanfaatkan posyandu lansia). 


\section{Hambatan-hambatan}

Informan dari penerima layanan menyatakan faktor penghambat yang menghambat keberlanjutan posyandu lansia yaitu karena jarang dilakukannya pemeriksaan oleh dokter, pemberian PMT tidak rutin, waktu yang terbatas, kalau sakit atau ada kesibukan tidak bisa datang, terlalu banyak kesibukan adat di desa. Seperti yang dikemukakan berikut ini:

"Ya, cuma kalau ga ada waktu ga dah saya keluar..." (Informan A5, lansia yang memanfaatkan posyandu lansia)

Selain hal diatas pada informan yang memanfaatkan posyandu lansia merasakan tidak puas atau biasa saja terhadap pelayanan posyandu yang diberikan, sehingga menyebabkan daya tarik lansia untuk datang ke posyandu menjadi berkurang. Hal tersebut disebabkan karena lansianya disuruh untuk meminta sumbangan kepada donatur untuk keberlanjutan posyandu, pemeriksaan tidak dilakukan oleh dokter, obatnya sedikit dan lansia tidak merasakan perubahan kesehatan terhadap tubuhnya. Seperti ungkapan berikut ini:

“..kurang puas, karena obat-obatannya juga kurang, rasanya ga juga puas...iya, sampai minta-minta sumbangan itu.....masalah itu juga kurang puas kalau tidak diperiksa oleh dokter.jadinya berkurang daya tarik kita itu untuk datang" (Informan A1, lansia yang memanfaatkan posyandu lansia)

Sedangkan hasil wawancara dengan informan yang tidak memanfaatkan posyandu lansia menyatakan bahwa faktor yang menyebabkan di desanya tidak berlangsung posyandu lansia yaitu kurangnya dukungan atau sosialisasi dari petugas puskesmas, pengetahuan lansia kurang, kurangnya dukungan dari kepala desa, lansia malas, merasa aman karena sudah mempunyai jaminan kesehatan dan lebih baik waktu yang ada digunakan untuk bekerja dari pada datang ke posyandu lansia. Seperti yang dikemukakan berikut ini:

"Oh faktor penyebab itu yang pertama dari puskesmas itu tidak pernah turun memberikan penjelasan kepada masyarakat...sosialisasi sama sekali tidak ada... (Informan B4, lansia yang tidak memanfaatkan posyandu lansia)

\section{Hambatan dari pemberi layanan}

Hasil wawancara dengan Camat dan kepala puskesmas di Marga menyebutkan bahwa faktor penghambat keberlanjutan posyandu lansia yaitu anggaran di Tabanan sangat terbatas untuk posyandu lansia sangat terbatas, tenaga dokter yang disediakan puskesmas kurang. Seperti yang dikemukakan berikut ini:

"...karena anggaran kita di Tabanan secara umum belum mencukupi." (Informan IKI, kepala puskesmas)

Selain hal tersebut diatas yang menjadi faktor penghambat berdasarkan wawancara mendalam dengan petugas puskemas terhadap keberlanjutan posyandu lansia adalah peralatan seperti alat-alat laboratorium yang ada di posyandu masih kurang serta peralatannya yang disediakan cepat rusak. Seperti kutipan wawancara berikut ini: 
“...sementara ini kita hanya menggunakan alat tensi, mungkin kendala kita kan jumlahnya. Cuma karena alatnya itu kan kita gunakan berbanyak jadi cepet rusak itu dah kendalanya. Selain itu peralatan laboratorium yang masih terbatas" (Informan IK2, petugas puskesmas)

Sedangkan hasil wawancara dengan kepala desa yang memiliki posyandu yang aktif dan tidak aktif menyatakan bahwa yang menjadi faktor penghambat keberlanjutan posyandu lansia yaitu karakter lansia di setiap desa berbeda, anggaran dari pemerintah tidak ada, antusias lansia kurang jika tidak diberikan imbalan, lansia susah untuk digerakkan dan waktu yang terbatas dari lansia. Seperti yang dikemukakan berikut ini:

"Respon dari lansianya juga, kan tergantung dari karakter masyarakat.. Selain itu lansia ga mau datang jika ga dikasi imbalan kayak PMT itu, lansia susah sekali kalau digerakkan" (Informan IK3, kepala desa yang posyandunya aktif)

Hasil wawancara dengan kader lansia menjadi penghambat terhadap keberlanjutan posyandu lansia yaitu jarangnya pemeriksaan yang dilakukan oleh dokter serta peralatan seperti timbangan yang disediakan di posyandu jumlahnya agak kurang. Seperti yang dikemukakan berikut ini:

“...dokter jarang, cuma sekali-sekali saja... Timbangan untuk lansia tidak ada terkadang meminjam dari puskesmas" (Informan IK5, kader lansia)

Variasi hambatan-hambatan internal puskesmas di Kecamatan Marga menjadi alasan lansia tidak datang ke posyandu lansia. Berdasarkan hasil wawancara mendalam, pengetahuan lansia yang memanfaatkan posyandu lansia lebih baik dari pada pengetahuan lansia yang tidak memanfaatkan posyandu lansia. Hal ini dapat kita lihat dari hasil wawancara mendalam mengenai pengetahuan informan tentang pengertian, tujuan, sasaran, dan bentuk kegiatan posyandu lansia, didapatkan data rata-rata informan yang memanfaatkan posyandu lansia lebih tahu dari pada informan yang tidak memanfaatkan posyandu lansia.

Pengetahuan yang salah tentang tujuan dan manfaat posyandu dapat menimbulkan salah persepsi yang pada akhirnya kunjungan lansia ke posyandu lansia menjadi rendah. Hasil penelitian ini memberikan informasi bahwa alasan terbesar informan tidak memanfaatkan posyandu lansia yang karena informan tidak tahu adanya pelayanan posyandu lansia.

Berdasarkan hasil wawancara mendalam didapatkan bahwa lebih dari sebagian lansia menyatakan puas terhadap pelayanan yang diberikan di posyandu lansia. Namun ada juga yang menyatakan tidak puas, hal tersebut lebih disebabkan karena tidak adanya dokter pada saat dilakukan pemeriksaan, lansia tetap merasakan sakit walaupun sudah dilakukan pengobatan serta obat yang disediakan di posyandu jumlahnya sedikit.

Teori health belief model menyebutkan bahwa individu akan memiliki persepsi yang positif terhadap suatu kegiatan, jika individu tersebut mendapatkan keuntungan dari melakukan tindakan tersebut. Dalam perceived benefit individu menilai keuntungan dalam memperoleh layanan kesehatan misalnya semakin sehat ketika sudah memperoleh layanan kesehatan, dan dalam perceived barrier individu menilai kerugian jika memperoleh layanan kesehatan. 
Dalam penelitian ini didapatkan hasil bahwa lansia merasakan kepuasan terhadap pelayanan yang diberikan, karena pada saat posyandu tersebut diadakan pemeriksaan laboratorium sehingga memiliki persepsi yang positif cenderung mengarah ke perceived benefit terhadap pelaksanaan posyandu lansia. Sehingga mendorong lansia untuk mengunjungi posyandu, dimana menurut mereka berkunjung ke posyandu memiliki daya tarik tersendiri. Berbanding terbalik dengan lansia yang merasakan kurang puas terhadap pelayanan posyandu yang diberikan, dimana lansia tersebut tetap merasakan sakit, kemudian disebabkan karena tidak adanya dokter yang memeriksa pada saat pelaksanaan posyandu, serta obatnya sedikit. Sehingga lansia tersebut memiliki persepsi yang negatif cenderung memiliki perceived barrier terhadap pelaksanaan posyandu lansia.

Persepsi seorang lansia sangat tergantung pada konsep lansia yang dimiliki oleh lansia sejak awal. Lansia sering beranggapan bahwa, jika lansia tersebut bisa melakukan kegiatan sehari-hari maka lansia tersebut beranggapan bahwa dirinya sehat sehingga cenderung lansia tidak akan mau untuk berkunjung ke posyandu. Persepsi negatif lansia tentang posyandu lansia menyebabkan mereka tidak tertarik untuk mengikuti posyandu lansia (Efnileli, 2013).

Dilihat dari segi sumber daya manusia terkait keberlanjutan posyandu lansia, penelitian ini menemukan faktor penghambat dalam pengembangan layanan posyandu lansia adalah jumlah tenaga dokter yang masih kurang. Dimana di puskesmas hanya terdapat 2 dokter umum, sehingga kesulitan dalam memberikan pelayanan dimana dokter memiliki tanggung jawab di puskesmas dan juga memiliki tanggung jawab dalam memberikan pelayanan kepada masyarakat di desa. Oleh sebab itu dokter memiliki beban kerja yang dirasakan berlebihan dengan banyaknya program yang ada puskesmas. Sedangkan faktorfaktor pendukung adalah jenis tenaga kesehatan yang lain seperti perawat, bidan serta tenaga kesehatan pendukung lainnya sudah memadai sehingga bisa memberikan pelayanan pada saat posyandu lansia.

Pandangan pemegang kebiijakan dinas kesehatan terkait masalah tenaga di puskesmas adalah merupakan permasalahan klasik di setiap Satuan Kerja Perangkat Daerah (SKPD). Masalah tenaga adalah wewenang kebijakan dari Badan Kepegawaian Daerah (BKD) Tabanan, sesuai dengan ketentuan regulasi dan kebutuhan perencanaan dari kepegawaian. Untuk mengatasi masalah tersebut strategi yang telah dijalankan oleh dinas kesehatan adalah dengan mengangkat tenaga kesehatan dengan sistem kontrak yang dilakukan oleh pemerintah daerah (Fadhilah, 2012).

Hasil penelitian ini menunjukkan bahwa informan yang memanfaatkan posyandu lansia mengetahui peralatan yang disediakan di posyandu, namun berdasarkan hasil wawancara mendalam menemukan jawaban yang bervariasi. Dimana ada lansia yang mengatakan jumlahnya sedikit sehingga perlu ditambahkan sehingga lansia tidak perlu menggunakan uang sendiri untuk membeli peralatan tersebut.

Menurut penelitian Fuadi (2008) terdapat hubungan bermakna antara adanya fasilitas kesehatan yang lengkap dengan pemanfaatan pelayanan kesehatan. Dimana lansia cenderung akan memanfaatkan posyandu lansia jika peralatan yang disediakan di posyandu lengkap. 
Hal tersebut senada dengan penelitian yang dilakukan oleh Fitriasih (2010) Sarana dan prasarana sangat mempengaruhi kunjungan lansia dalam berkunjung ke posyandu. Semakin lengkap sarana dan prasarana yang disediakan menyebabkan lansia akan semakin tertarik dalam melakukan kunjungan dan terdapat hubungan yang bermakna antara fasilitas kesehatan yang lengkap dengan pemanfaatan pelayanan kesehatan.

Menurut pandangan peneliti yang menjadi faktor penghambat dalam hal ketersediaan sarana dan prasarana adalah jumlah peralatan yang disediakan masih terbatas. Dimana di salah satu posyandu disebutkan bahwa untuk pemeriksaan cek darah, lansia dibebankan untuk membeli peralatan sendiri. Dimana saat posyandu lansia berlangsung terkadang jumlah lansianya banyak, sehingga terkadang kekurangan alat pemeriksaan darah. Oleh sebab itu lansia memiliki inisiatif untuk membeli pelaratan laboratorium secara swadaya sendiri.

Ketersedian sarana dan prasarana merupakan salah satu faktor yang berperan dalam perilaku kesehatan, dengan tersedianya peralatan ini akan memungkinkan para lansia untuk datang ke posyandu lansia. Hasil ini menunjukkan bahwa ada kecenderungan antara lansia yang bersikap positif terhadap pemanfaatan posyandu lansia. Sesuai dengan penelitian ini dapat disimpulkan bahwa sarana dan prasarana cenderung mempengaruhi pemanfaatan posyandu lansia (Razak, 2000).

Berdasarkan faktor-faktor tersebut, penelitian ini merekomendasikan strategi yang bisa dilakukan adalah diperlukan kerjasama antar instansi terkait misalnya kepala desa, kader lansia, dukungan puskesmas agar bisa membangkitkan posyandu yang tidak aktif. Hal tersebut disebabkan karena kegiatan posyandu lansia, tidak akan bisa berjalan jika hanya mengandalkan satu pihak saja diperlukan adanya hubungan yang baik antar instansi tersebut. Selain itu bisa dengan membangkitkan kesadaran lansia tentang arti penting kesehatan bagi lansia.

\section{SIMPULAN DAN SARAN}

\section{Simpulan}

Faktor predisposisi terhadap pelaksanaan posyandu lansia adalah pengetahuan dari lansia, persepsi lansia terhadap keuntungan yang dirasakan jika mengikuti posyandu, kualitas pelayanan yang diberikan di posyandu lansia serta adanya keinginan untuk hidup secara sehat.Faktor pemungkin terhadap pelaksanaan posyandu lansia yaitu ketersediaan SDM, sarana dan prasarana serta waktu yang dimiliki lansia. Faktor penguat terhadap pelaksanaan posyandu lansia adalah adanya dukungan dari petugas puskesmas, dukungan keluarga serta kepala desa. Hal-hal yang menghambat keberlanjutan posyandu lansia pada posyandu yang pelaksanaanya aktif setiap bulan adalah kurangnya pemeriksaan yang dilakukan oleh dokter, waktu lansia yang terbatas karena kesibukan di rumah tangga, jarangnya diberikan PMT pada saat pelaksanaan di posyandu, serta peralatan yang disediakan di posyandu masih dalam keadaan kurang, kurangnya dukungan dari petugas puskesmas dan kepala desa, faktor sosial ekonomi dari lansia itu sendiri, kesadaran lansia masih kurang. 


\section{Saran}

Bagi Puskesmas : Meningkatkan sosialisasi posyandu lansia ke masyarakat melalui tenaga promkes yang ada di puskesmas untuk meningkatkan kesadaran lansia agar datang ke posyandu.Bagi Kader Lansia : Diperlukan adanya pelatihan secara periodik kepada kader lansia terkait pelaksanaan posyandu lansia.Bagi peneliti selanjutnya : Diperlukan penelitian selanjutnya dengan mengaitkan variabel-variabel lain seperti kebijakan, pendanaan dan dukungan terhadap keberlanjutan posyandu lansia.

\section{DAFTAR PUSTAKA}

Abikusno, Nugroho. 2013. Gambaran Kesehatan Lanjut Usia. Buletin Lansia Jendela dan Informasi Kesehatan Semester 1. Hal 15 Topik Kelanjutusiaan Sehat Menuju masyarakat Sehat.

Amalia,Rizki. 2014. Beberapa Faktor yang Berhubungan dengan Keikutsertaan Lansia dalam Posyandu Lansia di Desa Ngablak Kecamatan Ambarawa Kabupaten Semarang .Skripsi. Stikes Ngudi Waluyo. Semarang

Dinas Kesehatan. 2017. Profil Dinas Kesehatan Kabupaten Tabanan. Tabanan: Pemkab Tabanan.

Departemen Kesehatan RI. 2010. Pedoman Pembinaan Kesehatan Lanjut Usia. Jakarta: Direktorat Bina Kesehatan Komunitas.

Efnileli.2013. Analisis Implementasi Program Posyandu Lansia di Kota Cirebon .Tesis. Undip. Semarang

Fadhilah, Nur. 2012. Faktor-faktor Yang Berhubungan Dengan Pemanfaatan Posyandu Lansia di Desa Blitarejo Kecamatan Gadingrejo Kabupaten Pringsewu Tahun 2012.2 Dari http://www.scribd.com/doc/178846482/Dengan-Pemanfaatan-PosyanduLansia diakses tanggal 29 Mei 2015.

Fuadi. 2008. Studi Fenomenologi Motivasi Lansia Dalam Memanfaatkan Posyandu Lansia di Kelurahan Sidomulyo Kecamatan Matesih Kabupaten Karanganyar - Penelusuran Google. Available at: Https://Www.Google.Co.Id/?Gws_Rd=Cr,Ssl\&Ei=Vnlzvsvgby2eugs6jxgcq \#Q=Studi+Fenomenologi+Motivasi+Lansia+Dalam+Memanfaatkan+Posya ndu+Lansia+Di+Kelurahan+Sidomulyo+Kecamatan+Matesih+Kabupaten+ Karanganyar [Accessed December 18, 2015f]

Fitriasih, Nina. 2010. Analisis Faktor yang Berhubungan dengan Pemanfaatan Pelayanan Kesehatan di Posyandu Lansia di Wilayah Kerja Puskesmas Semili Raya Kabupaten Lampung Utara .Skripsi. Univesitas Indonesia. Depok

Razak, Amran. 2000. Pemanfaatan Pelayanan Kesehatan Masyarakat Pesisir. Makassar: Kalammedia Pustaka. 